\title{
Simulating Long-Term Effects of Bioenergy Extraction on Dead Wood Availability at a Landscape Scale in Sweden
}

\author{
Anouschka R. Hof ${ }^{1,2, *}$, Therese Löfroth ${ }^{2}$, Jörgen Rudolphi ${ }^{2}$, Timothy Work ${ }^{3}$ and \\ Joakim Hjältén ${ }^{2}$ \\ 1 Resource Ecology Group, Wageningen University, Droevendaalsesteeg 3, 6708 PB Wageningen, \\ The Netherlands \\ 2 Department of Wildlife, Fish, and Environmental Studies, Swedish University of Agricultural Sciences, \\ Umeå 90183, Sweden; Therese.Lofroth@slu.se (T.L.); Jorgen.Rudolphi@slu.se (J.R.); \\ Joakim.Hjalten@slu.se (J.H.) \\ 3 Department of Biological Sciences, University of Quebec at Montreal (UQAM), Montréal, QC H2X 1Y4, \\ Canada; work.timothy@uqam.ca \\ * Correspondence: Anouschka.Hof@wur.nl; Tel.: +31-61-835-1490
}

Received: 29 June 2018; Accepted: 25 July 2018; Published: 27 July 2018

\begin{abstract}
Wood bioenergy may decrease the reliance on fossil carbon and mitigate anticipated increases in temperature. However, increased use of wood bioenergy may have large impacts on forest biodiversity primarily through the loss of dead wood habitats. We evaluated both the large-scale and long-term effects of different bioenergy extraction scenarios on the availability of dead wood and the suitability of the resulting habitat for saproxylic species, using a spatially explicit forest landscape simulation framework applied in the Swedish boreal forest. We demonstrate that bioenergy extraction scenarios, differing in the level of removal of biomass, can have significant effects on dead wood volumes. Although all of the scenarios led to decreasing levels of dead wood, the scenario aimed at species conservation led to highest volumes of dead wood (about $10 \mathrm{~m}^{3} \mathrm{ha}^{-1}$ ) and highest connectivity of dead wood patches (mean proximity index of 78), whilst the scenario aimed at reaching zero fossil fuel targets led to the lowest levels (about $8 \mathrm{~m}^{3} \mathrm{ha}^{-1}$ ) and least connectivity (mean proximity index of 7). Our simulations stress that further exploitation of dead wood from sites where volumes are already below suggested habitat thresholds for saproxylic species will very likely have further negative effects on dead wood dependent species.
\end{abstract}

Keywords: boreal forest; biodiversity; biofuel; modelling; saproxylic species

\section{Introduction}

Reducing reliance on fossil carbon will likely play a key role in any strategy aimed at mitigating global warming. In forested regions of the world, wood bioenergy has the potential to become a significant source of bioenergy, while simultaneously mitigating climate change. Managing forest resources will therefore become increasingly important; particularly given recent legislative efforts to reduce greenhouse gas emissions and increased use of renewable energy sources (e.g., European Union (EU) targets concerning reductions) [1]. However, political goals are all too often formulated without regard for possible conflicts among stakeholders and management objectives. For example, strategies to mitigate or adapt to climate change are likely to conflict with environmental goals, such as biodiversity conservation [2]. This is because intensive bioenergy extraction is likely to have a negative impact on forest species, such as those that are associated with dead wood [3,4]. Several studies have shown short-term negative effects of biofuel extraction on biodiversity $[5,6]$. 
Dead wood is a key structure for biodiversity in boreal forest [7-9]. Numerous species of insects, wood fungi, lichens and bryophytes are dependent on dead wood and predators, like woodpeckers, utilize saproxylic (wood living) insects as prey [9]. In a forest landscape that is shaped by natural disturbances, dead wood is continuously created through fires, storms, and insect outbreaks [10,11]. Several studies have aimed to elaborate with thresholds of dead wood, above which saproxylic species would benefit, but due to the differences in demands by species it has been deemed impossible to set satisfying thresholds of dead wood that would be appropriate at the stand level that fit all species [12]. Based on a review of dead wood threshold data, Müller and Bütler [13] suggested that it would be necessary to aim for a number of forest stands with 20 to $50 \mathrm{~m}^{3} \mathrm{ha}^{-1}$ of dead wood in a network of forest landscapes to benefit species conservation, and not for a lower mean amount of dead wood in all stands. This was confirmed by Work and Hibbert [14]. In landscapes that are dominated by anthropogenic disturbances, including timber extraction and suppression of natural disturbances, such as fire, the volumes of dead wood have decreased to levels below what is sustainable for species conservation in the long term $[7,13]$. The amount of dead wood found in managed forests in Sweden is for instance only around $<1-13 \mathrm{~m}^{3} \mathrm{ha}^{-1}$, whilst levels of dead wood in unmanaged forest vary from 11 to $91 \mathrm{~m}^{3} \mathrm{ha}^{-1}[15,16]$. This means that many species that are dependent on dead wood have declined in managed landscapes $[17,18]$. Traditionally, forest management has mainly impacted the larger fractions of dead wood and it is also these fractions that are considered to be the most valuable for biodiversity. Smaller fractions consisting mainly of branches and tops have not declined at the same rate and nowadays constitute the main part of dead wood in the forest $[19,20]$. The implementation of bio fuel extraction on a larger scale is expected to impact the volumes of slash and stumps available, which might impact saproxylic species in the long term [6,21]. It is therefore of utmost importance that we assess the impact of bioenergy extraction on dead wood availability to develop management strategies that can mitigate the negative effects on saproxylic organisms.

Our understanding of large-scale and long-term effects on the availability of dead wood across forest landscapes after bio fuel extraction is limited. Consequently, extensive biofuel extraction has been restricted, e.g., stump harvest is currently limited to $1 \%-2 \%$ of the clear-cuts in Sweden, mainly due to restrictions in the Swedish Forest Stewardship Council (FSC) standard. However, the extraction of stumps and slash in combination with other wood fuels could theoretically provide $40 \mathrm{TWh}$ of energy in Sweden by 2020 [22] and could therefore play a major role in Sweden's climate change mitigation strategies. Before large-scale bioenergy extraction can be implemented, we need a better understanding of long-term landscape effects. This is important for decisions makers, forest owners, and Non-governmental organizations (NGOs) to evaluate trade-offs among economic, environmental, and societal values. For an in-depth understanding of the effect of bioenergy harvest on saproxylic organisms, we first need information on the long-term effect of different bioenergy extraction scenarios on the availability of dead wood substrates in the landscape. Forest landscape simulation models may be helpful in assessing impacts of, amongst others, anthropogenic disturbances on forest ecosystems and can be used to determine the appropriate levels of management and restoration for species conservation [23].

The objective of this study was to obtain an increased understanding of the landscape scale impacts of bioenergy extraction on the long term availability of dead wood in the Swedish forest ecosystem. We therefore used a forest landscape simulation model (LANDIS-II) [24] to simulate the impact of different scenarios of bioenergy extraction on the availability and connectivity of dead wood in a forest landscape in Sweden. LANDIS-II allows for the simulation of forest dynamics over large spatial scales and long timescales and accounts for individual tree species, biomass accumulation and decomposition, carbon sequestration, seed dispersal, climate change, harvesting, and other natural disturbances $[24,25]$. The model has been extensively validated and used in boreal forests across both Europe and Northern America $[23,26,27]$. LANDIS-II is the core model to which various optional extensions can be linked to incorporate ecological and anthropogenic processes [28-30]. We simulated a scenario that reflects the current conventional bioenergy extraction, and a scenario that reflects a 
prognosis in which a greater proportion of bioenergy is extracted. We further simulated the impact of a severe scenario in which the entire tree, including foliage, is extracted to reflect a situation in which reaching zero fossil fuel targets is society's main aim. We also simulated the impact of a conservation scenario in which no bioenergy is extracted and a smaller proportion of the tree is harvested, to reflect a situation in which reaching biodiversity conservation targets is society's main aim.

\section{Materials and Methods}

\subsection{Study Site}

We simulated the forest dynamics of a $125 \mathrm{~km}^{2}$ large area in the counties of Västra Götalands Län and Värmlands Län in Sweden (Figure 1). This region was used in a previous study by Hof and Hjältén [23] that simulated the impacts of forest restoration practices on the suitability of the study region for an endangered woodpecker species, the white-backed woodpecker (Dendrocopos leucotos). Within the study region, there are managed forests and there are several protected areas and restoration sites to safeguard the presence of the woodpecker. The landscape is currently dominated by relatively young stands (average age of 40) of Norway spruce (Picea abies (L.) Karsten, henceforth referred to as spruce), Scots pine (Pinus sylvestris L., henceforth referred to as pine), and silver birch (Betula pendula Roth., henceforth referred to as birch). The current amount and composition of dead wood in the study region is not known exactly. We, however, assumed that the levels and composition of the dead wood in the managed forest in the study region reflect that of amounts and species compositions found in the counties the study region is situated in $\left(5.9 \mathrm{~m}^{3} \mathrm{ha}^{-1}\right.$ to $8.7 \mathrm{~m}^{3} \mathrm{ha}^{-1}$ of dead wood of which $29 \%-39 \%$ is pine, $41 \%-48 \%$ is spruce, and $20 \%-23 \%$ is consisting of broadleaved species [16]). Amounts of dead wood in the protected areas and restoration sites are likely remarkably higher (11 to $91 \mathrm{~m}^{3} \mathrm{ha}^{-1}$ [15]).

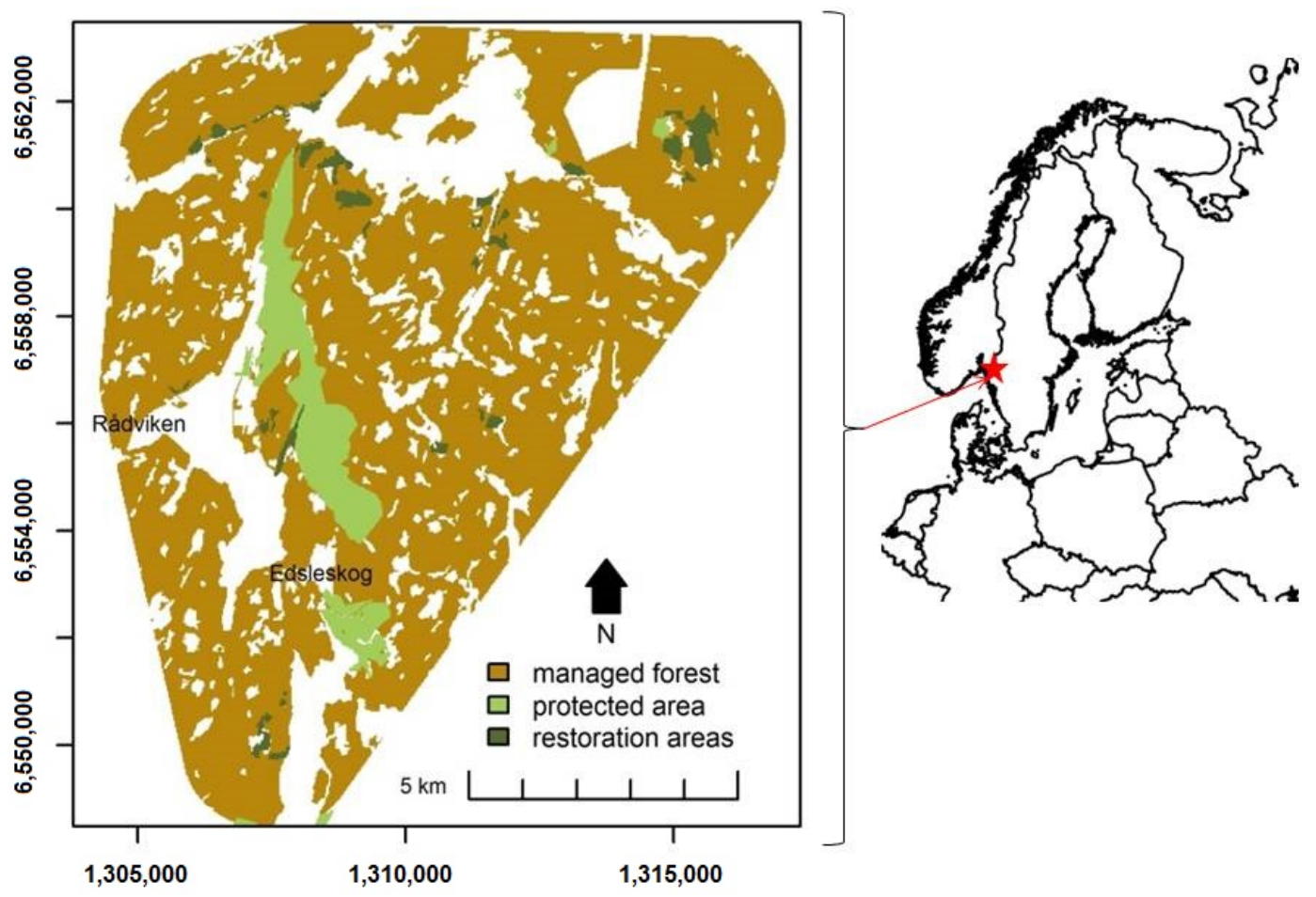

Figure 1. The study site.

\subsection{Forest Dynamics Simulation}

We used LANDIS-II [24] to simulate the large-scale and long-term effects of different levels of bioenergy extraction on dead wood availability. As mentioned, there are protected areas and restoration 
sites in the study region, but for the purpose of this simulation study, we treated these areas similar to the managed areas, i.e. we also allowed harvest to occur in the protected areas and restoration sites. To obtain a realistic baseline, we used, in addition to the core of LANDIS-II, the Base Harvest extension v2.2 [31] in combination with the Forest Carbon Succession Extension v.2.0 (ForCS) [28] to simulate the effect of different bioenergy extraction strategies on the forest dynamics and carbon pools. We chose not to simulate the effects of natural disturbances like fire, pests, storm events, and browsing on the forest. This was because (1) not all disturbances can be simulated satisfactory, (2) we lacked knowledge about the effect of many disturbances in our study region, (3) the current impact of e.g., natural fire on the landscape is nearly zero in our study region due to effective fire suppression measures [32,33], but most importantly, (4) the availability of dead wood levels in the landscape due to bioenergy extraction may be obscured by dead wood accumulation that is caused by natural disturbances. In addition, most of Sweden's managed forests are shaped by anthropogenic pressures $[34,35]$, and the objective of our study was specifically to study the impact of bioenergy extraction and not of natural disturbances.

The initial forest community that forms the basis of the simulations and is needed for the core of the model is described in detail in the study by Hof and Hjälten [23]. It was based on the spatial forest inventory dataset kNN-Sweden (http:/ / skogskarta.slu.se/). It contains information on age, species, and timber stock of the woodlands in Sweden at a $25 \mathrm{~m} \times 25 \mathrm{~m}$ scale. The information is based on forest data from the Swedish National Forest Inventory (NFI) combined with satellite images from SPOT 4 and SPOT 5 [36]. Other than data for the three dominant species in the study region (spruce, pine and birch), there is data available for pedunculate oak (Quercus robur L. denoted as oak) and for a category called 'other broadleaf', which consists of species, like Norway maple (Acer platanoides L.), common alder (Alnus glutinosa L.), and Eurasian aspen (Populus tremula L.). These species however only make up a small portion of the species in the landscape. The principle species included in this study are therefore spruce, pine, birch, pedunculate oak, and other broadleaf. We followed the methods described in Hof and Hjältén [23] to simplify the initial forest community to a total of 44 communities that differed in species composition and age; a process that is necessary for LANDIS-II to be able to process the data.

Species parameters required by ForCS include tree and leaf longevity, sexual maturity, shade tolerance, effective seed dispersal distance, maximum seed dispersal distance, vegetative reproduction probability, minimum sprout age, and maximum sprout age (Table 1). Values for each species were obtained from the literature [26,37-55]. Species parameters for the 'other broadleaf' category were based on maximum/minimum values of a suit of deciduous species occurring in the region. ForCS calculates how cohorts regenerate, age, and die. Changes in cohort biomass $\left(\mathrm{g} \mathrm{C} \mathrm{m}^{-2}\right)$, dead organic matter (DOM) and soil carbon are tracked over time [28]. The modelling of wood decay and provision of by ForCS required decay rates specified per species and carbon pool largely follows the methods used in Kurz et al. [53].

Table 1. Important species parameters required by ForCS. TL: tree longevity (years), LL: leaf longevity (years), SM: sexual maturity (years), ST: shade tolerance (1 is lowest tolerance, 5 is highest tolerance), ED: effective seed dispersal distance (meters), MD: maximum seed dispersal distance (meters), VR: vegetative reproduction probability $(0 \leq x \leq 1)$, MIN: minimum sprout age (years), and MAX: maximum sprout age (years).

\begin{tabular}{cccccccccc}
\hline Species & TL & LL & SM & ST & ED & MD & VR & MIN & MAX \\
\hline Picea abies (L.) Karsten & 500 & 5 & 50 & 3 & 50 & 400 & 0.2 & 0 & 500 \\
Pinus sylvestris L. & 500 & 3 & 10 & 1 & 50 & 1000 & 0 & 0 & 0 \\
Betula pendula Roth. & 250 & 1 & 10 & 2 & 50 & 200 & 0.4 & 0 & 200 \\
Quercus robur L. & 1000 & 1 & 40 & 3 & 20 & 3000 & 0.2 & 0 & 500 \\
Other broadleaf & 250 & 1 & 10 & 3 & 40 & 1000 & 0.2 & 0 & 250 \\
\hline
\end{tabular}




\subsection{Bioenergy Extraction}

We used ForCS to remove forest biomass from various pools from the landscape. In ForCS, it is possible to track the carbon that is harvested, and the user can control amongst others the proportion of the live merchantable stemwood, the dead standing merchantable stemwood, and the dead branches, stumps, and small trees that are harvested and the proportion that goes to the DOM pool. Variations in these proportions formed the core of our study. The following carbon pools that ForCS tracks over time were relevant for this study: (1) live stemwood of merchantable size, (2) branches and stumps of newly harvested trees, small trees, (3) foliage, (4) coarse roots, and (5) fine roots. Based on these pools, we defined four different bioenergy extraction strategies that would be implemented whenever a stand is harvested. First, we simulated a scenario reflecting what we deem to be conventional harvest in Sweden in which, during each harvest event, $95 \%$ of the live stemwood of merchantable size is removed from the landscape to go to the forest product sector and the remainder stays behind and transfers to the DOM pool. Second, we simulated a scenario in which limited additional biomass is removed when compared to the conventional scenario; a scenario that we call the prognosis. In this scenario, in addition to the conventional harvest $30 \%$ of the branches and stumps of newly harvested trees and small trees, and $10 \%$ of the coarse roots is removed from the landscape. Third, we simulated a severe bioenergy extraction scenario to reflect a situation that zero fossil fuel usage is society's main aim. In addition to the $95 \%$ of the live stemwood of merchantable size, $100 \%$ of the foliage and the branches and stumps of newly harvested trees, and small trees as well as $10 \%$ of the coarse roots is removed from the landscape in this scenario. Fourth, we simulated a conservation scenario to reflect a situation in which biodiversity conservation is society's main aim. In this scenario just $80 \%$ of the live stemwood of merchantable size is removed from the landscape (Table 2). In none of our simulations, we removed dead standing stemwood of merchantable size or since long dead branches, stumps, and small trees from the landscape, since this is not promoted in Sweden [56].

Table 2. Proportion of the pools removed from the landscape after each harvesting event per scenario, the remainder of the pools go to the dead organic matter pool.

\begin{tabular}{ccccc}
\hline Biomass Pools & Conventional Harvest & Prognosis & Severe Extraction & Conservation \\
\hline Live stemwood of merchantable size & $95 \%$ & $95 \%$ & $95 \%$ & $80 \%$ \\
Branches and stumps of newly & $0 \%$ & $30 \%$ & $100 \%$ & $0 \%$ \\
harvested trees, small trees & $0 \%$ & $0 \%$ & $100 \%$ & $0 \%$ \\
Foliage & $0 \%$ & $10 \%$ & $10 \%$ & $0 \%$ \\
Coarse roots & $0 \%$ & $0 \%$ & $0 \%$ & $0 \%$ \\
Fine roots & & & \\
\hline
\end{tabular}

The harvest strategies during which the bioenergy extraction scenarios were implemented reflect current strategies in Sweden based on the Swedish forestry statistics from 2013 [57]: a clear-cut strategy in which all trees that are older than 80 years were harvested and Scots pine and Norway spruce were planted, and two thinning strategies; in one the youngest cohorts are harvested, in the other stands are thinned irrespective of age. Note that in all scenarios, the harvest level and frequency was the same, only the proportion of the different pools transferring to either the forest product sector or the DOM pool changed.

\subsection{Analyses}

We ran a simulation for each scenario for 100 years, 10 times, and at a $25 \mathrm{~m} \times 25 \mathrm{~m}$ scale. The 10 replicates were run to capture the variability in carbon dynamics caused by the stochastic representation of harvest disturbances. To convert the output of ForCS, which is delivered in $\mathrm{g} \mathrm{C} \mathrm{m}^{-2}$, to $\mathrm{m}^{3} \mathrm{ha}^{-1}$, we used the wood density of the different species as reported by the wood database (http://www.wood-database.com) and the fraction of carbon in dry wood. We used data from Mäkinen et al. [48], who found an average carbon concentration of about 50\% in Scots pine, Norway spruce and silver birch for both snags and logs in Finland. The carbon concentration in dead snags in 
decay class 1 (described as "recently dead tree, wood still hard, knife blade penetrates a few millimeters, bark normally intact") of pine was $50.07 \%$, of spruce $50.12 \%$, and of birch $49.59 \%$ [48]. These figures are similar to the conversion factors from raw volume per decay class to dry weight for Norway spruce and Scots pine developed by Sandström et al. [58]. They estimated a mean carbon concentration of $51.20 \%$ in pine and $50.03 \%$ in spruce over all the decay classes. These values also concur with, e.g., the 51\% C content in dead wood assumed by Krankina \& Harmon [59] following Sollins et al. [60]. The carbon concentration in dead wood of pedunculate oak and 'other broadleaf' was based on that of birch.

We set the threshold for dead wood at $20 \mathrm{~m}^{3} \mathrm{ha}^{-1}$, as per the guidelines set by Müller and Bütler [13], to quantify the amount of potentially suitable area for saproxylic species in general. It must be noted that the amounts of dead wood resulting from the simulations include all dead wood, not only dead wood above a certain diameter. Both the amount of dead wood and the spatial aggregation of areas with relatively high amounts of dead wood in the landscape are important for species [61]. The importance of the spatial aggregation of high amounts of dead wood in the habitat is to a large extent dependent on species' dispersal capacity. Since we did not focus on individual species in our study, we used the mean proximity index, which was originally developed by Gustafson and Parker [62] and considers both the size and the proximity distance of all patches with suitable habitat that have edges within a specified search radius of a focal patch of suitable habitat. It measures the degree of isolation of patches with suitable habitat and the degree of fragmentation of the suitable habitat within the specified landscape [63]. We used FRAGSTATS v4 [64] to calculate the proximity index. We set the search radius to $5000 \mathrm{~m}$. The proximity index value represents the level of connectivity of, in our case areas with relatively high amounts of dead wood. It however has no units and the values are thus only used for comparison: the higher the value the better connected. We also calculated the number of patches with high amounts of dead wood in the landscape and calculated the splitting (SPLIT) index in which the SPLIT index = 1 when the landscape consists of a single patch and the SPLIT index increases as the landscape is increasingly subdivided into smaller patches [63].

We used R version 3.2.2 [65] and the packages 'Raster' [66] and 'ggplot2' [67] for the analyses and graphical representation. We used the Wilcoxon signed rank test to assess whether, after 100 years of simulation, possible differences between amounts of dead wood were significantly dependent on the bioenergy extraction strategies. We used the Kruskal-Wallis rank sum test to assess whether there were significant differences in patch aggregation between the bioenergy extraction scenarios. Since the 10 replicates were used to represent the sample variability, the statistical tests only evaluated whether the difference between indicators was greater than the inter-annual variability created by disturbances. To clarify, we used the test to assess whether there were significant differences between the mean amount of dead wood time-series of the 10 replicates for the conventional harvest and the mean amount of dead wood time-series of the 10 replicates for the other bioenergy extraction scenarios.

\section{Results}

\subsection{Levels of Dead Wood in the Landscape}

Based on our simulation, initial levels of dead wood (including all dead wood, irrespective of diameter) in the landscape were around $15 \mathrm{~m}^{3} \mathrm{ha}^{-1}$ (Figure 2). Most of the dead wood consisted of spruce $(47 \%)$ and pine $(30 \%)$, whilst oak $(10 \%)$, birch $(6 \%)$, and other broadleaf $(6 \%)$ made up smaller amounts of the dead wood material (Figure 3). The amount of dead wood increased in the first twenty years of the simulation. After this initial period, the amount of dead wood quickly decreased and only stabilized at the end of the 100-year simulation around 8 to $10 \mathrm{~m}^{3} \mathrm{ha}^{-1}$, depending on the bio extraction scenario (Figure 2). The severe and prognosis scenario resulted in significantly lower amounts of dead wood than the conventional scenario (Wilcoxon signed rank test, prognosis: test-statistic $V=454, p<0.001$, severe: $V=18, p=0.016$ ). The conservation scenario, on the other hand, 
resulted in a significantly higher amount of dead wood than the conventional scenario (Wilcoxon signed rank test: $V=1784, p=0.001)$.

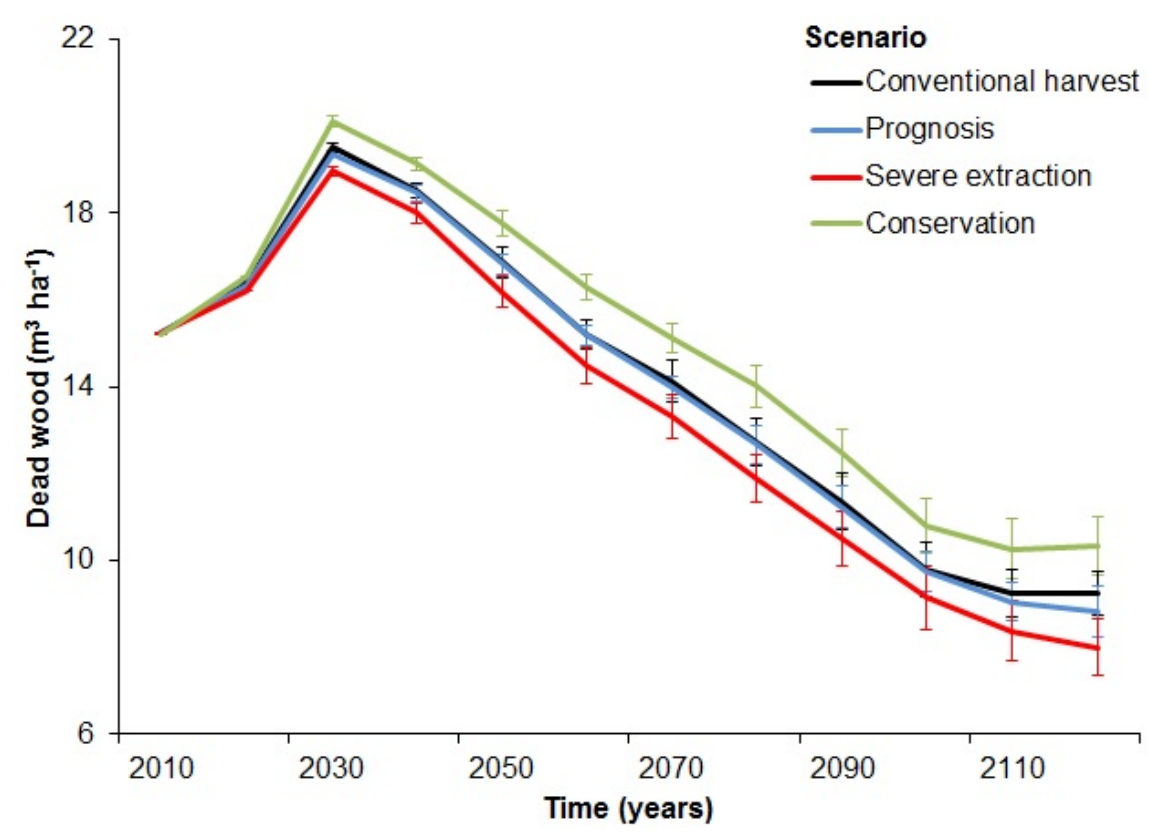

Figure 2. Levels of dead wood over time per bioenergy extraction scenario. Differences between the conventional harvest scenario and the other three bioenergy extraction scenarios were significant $(p<0.05)$.

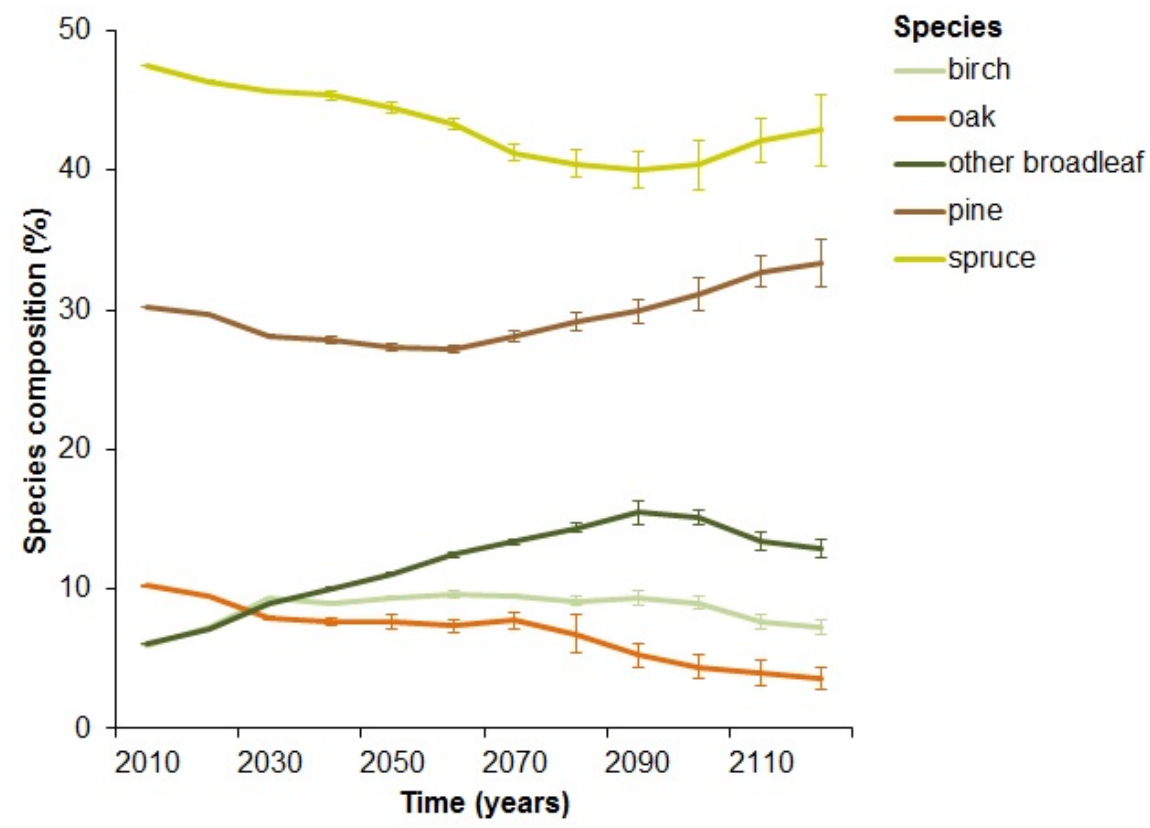

Figure 3. Species composition of the dead wood in percentage over time under the conventional extraction scenario.

\subsection{Consequences for Biodiversity}

According to our model, $9.5 \%$ of $25 \mathrm{~m} \times 25 \mathrm{~m}$ plots had more than $20 \mathrm{~m}^{3} \mathrm{ha}^{-1}$ dead wood at the beginning of the simulation. The amount of dead wood however declined after 100 years of bioenergy extraction. Under the conventional scenario, only $2 \%$ of the plots had more than $20 \mathrm{~m}^{3} \mathrm{ha}^{-1}$ 
dead wood after 100 years of extracting bioenergy (Figure 4a). However, both under the prognosis scenario and the severe scenario, the situation became even worse: under the prognosis scenario only $1.5 \%$ of the plots had more than $20 \mathrm{~m}^{3} \mathrm{ha}^{-1}$ of dead wood and under the severe scenario less than $0.1 \%$ of the plots had a high level of dead wood Even under the conservation scenario, the mean number of plots that contain more than $20 \mathrm{~m}^{3} \mathrm{ha}^{-1}$ dead wood was only $2.2 \%$. These differences were significant (Kruskal-Wallis $\chi^{2}=36.585, d f=3, p<0.001$ ) The number of patches (a patch can contain multiple plots) with more than $20 \mathrm{~m}^{3} \mathrm{ha}^{-1}$ dead wood was after 100 years of simulation the highest under the conservation scenario and the lowest under the severe scenario (Figure $4 \mathrm{~b}$ ), the differences being significant (Kruskal-Wallis $\chi^{2}=36.609, d f=3, p<0.001$ ) and more than twofold between the conservation and the severe scenario. The proximity index showed that these patches with relatively high levels of dead wood were significantly better connected under the conservation scenario (mean proximity index of 78) than under the other scenarios (Kruskal-Wallis $\chi^{2}=35.633, d f=3, p<0.001$ ), again the severe scenario being the least beneficial for connectivity, having a mean proximity index of 7 (Figure 4c). The patches with relatively high amounts of dead wood were also significantly most 'split' in the landscape under the severe scenario, according to the SPLIT index (Figure 4d) (Kruskal-Wallis $\chi^{2}=35.760, d f=3, p<0.001$ ). Figure 5 shows the spatial aggregation of the patches with relatively high levels of dead wood in the landscape.

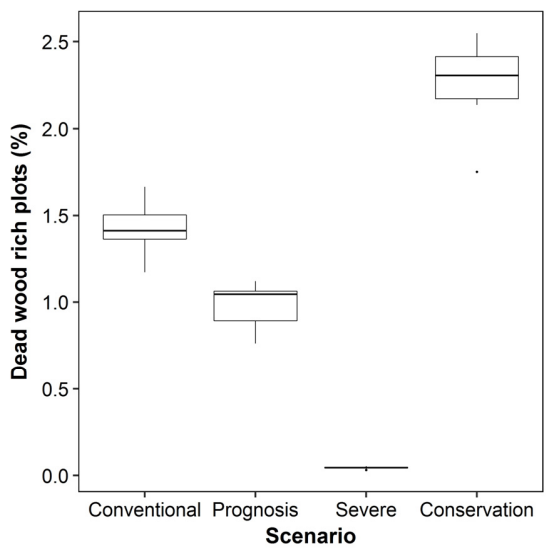

(a)

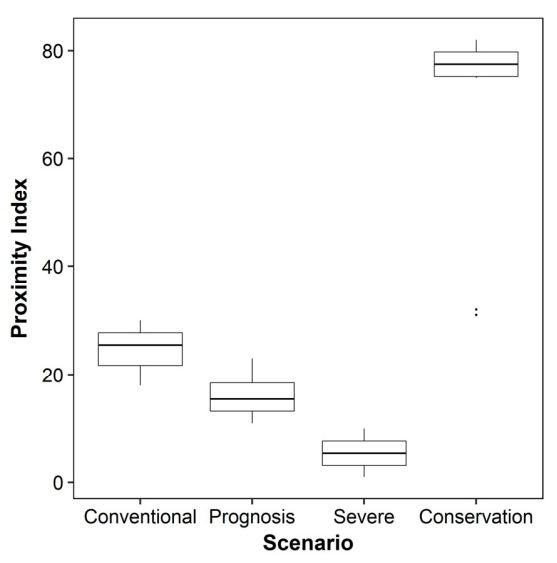

(c)

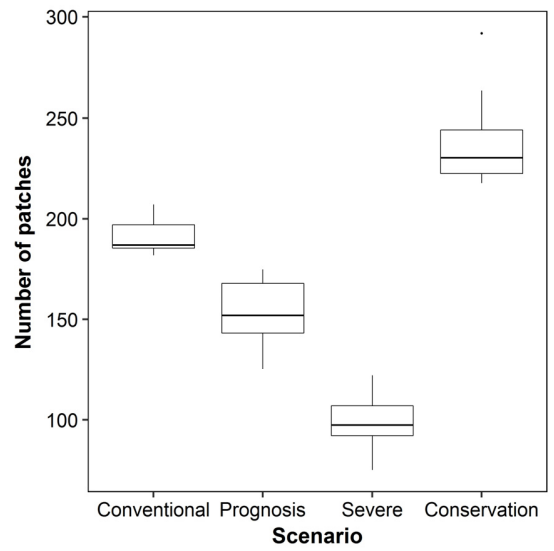

(b)

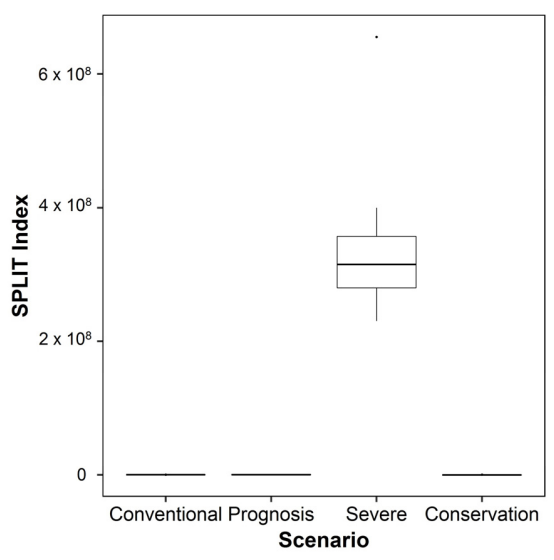

(d)

Figure 4. Boxplots showing the differences between: (a) Percentage of $25 \mathrm{~m} \times 25 \mathrm{~m}$ plots with dead wood levels $>20 \mathrm{~m}^{3} \mathrm{ha}^{-1}$; (b) Number of patches (a patch can contain multiple plots) with dead wood levels $>20 \mathrm{~m}^{3} \mathrm{ha}^{-1}$; (c) Proximity index between patches with dead wood levels $>20 \mathrm{~m}^{3} \mathrm{ha}^{-1}$; and (d) SPLIT index of the forest landscape, per bioenergy extraction scenario. All of the differences are significant $(p<0.001)$. 


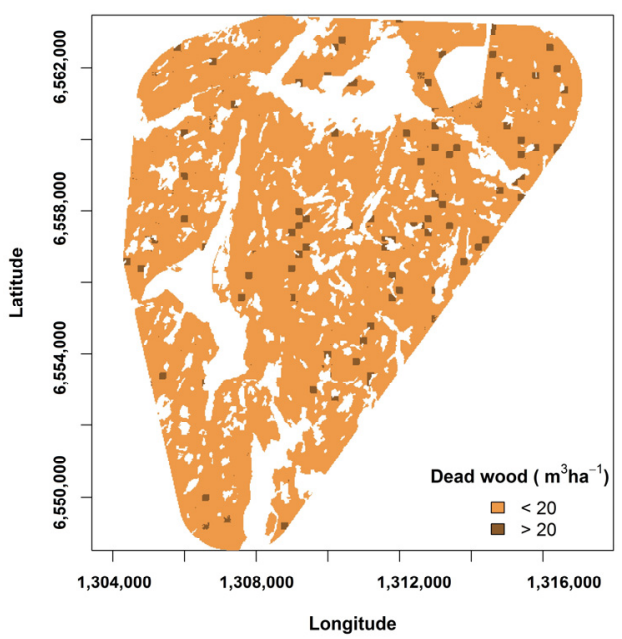

(a)

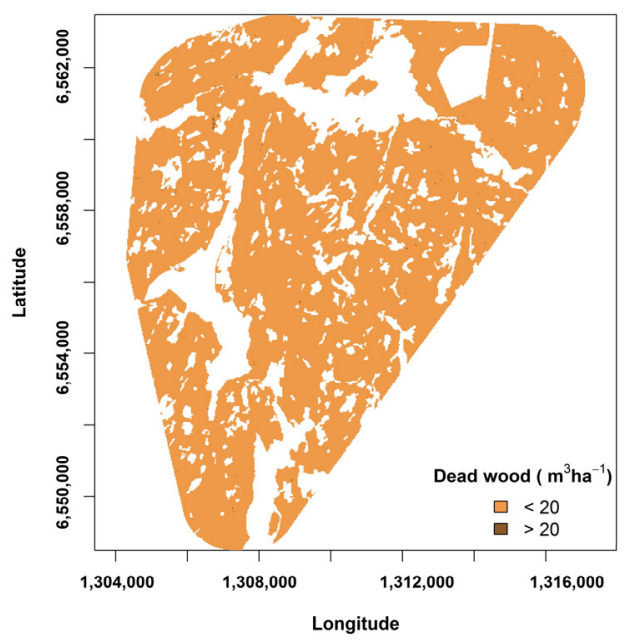

(c)

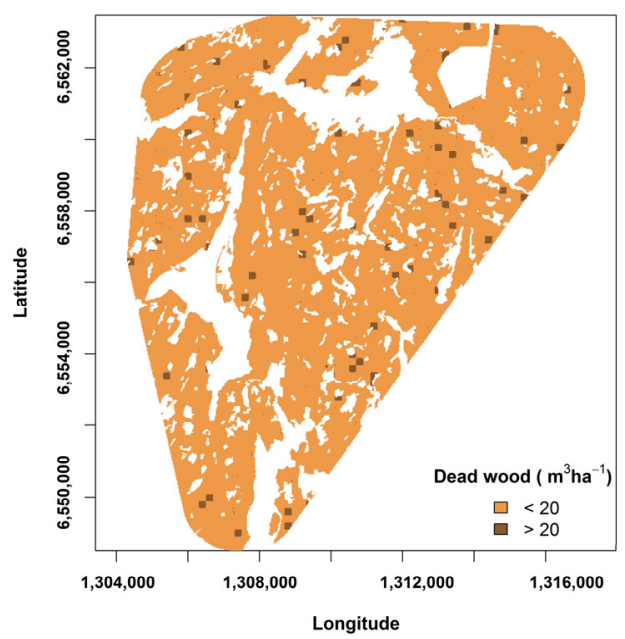

(b)

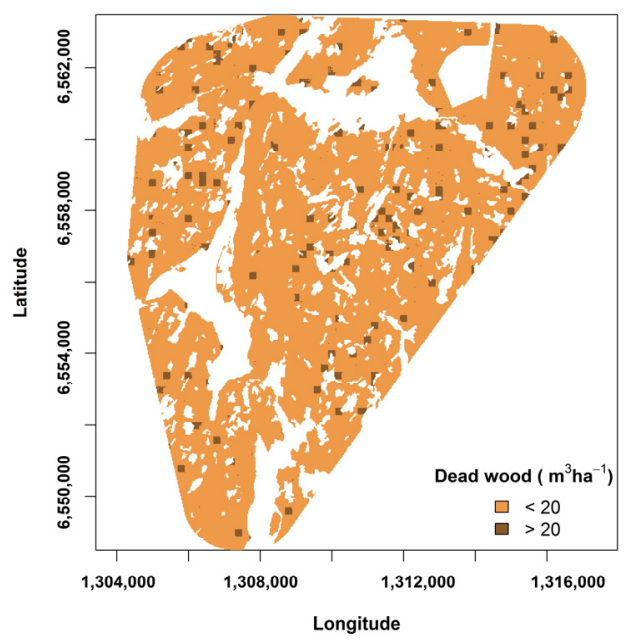

(d)

Figure 5. Spatial arrangement of dead wood levels after 100 years of simulation: (a) Under the conventional scenario in year 2110; (b) Under the prognosis scenario in year 2110; and (c) Under the severe scenario in year 2110; (d) Under the conservation scenario in year 2110.

\section{Discussion}

Based on our simulations, initial dead wood volumes were estimated to be ca. $15 \mathrm{~m}^{3} \mathrm{ha}^{-1}$, which is slightly more than the amount of dead wood found in managed forests in Sweden $[15,16]$. However, the fact that there is a sizeable protected area located in our study region and levels of dead wood in unmanaged forests in Sweden are remarkably higher than in the managed forest [15], gives some credibility to the initial levels of dead wood estimated by our model. Moreover, over the last few decades, levels of dead wood have been significantly increasing in managed forests in Sweden due to recognition of the importance of dead wood for biodiversity $[68,69]$. The composition of the dead wood, as simulated by our model, was also consistent with dead wood composition observed in neighboring regions. In our simulations most of the dead wood consisted of pine and spruce, whilst birch, oak, and broadleaf only made up small amounts of the dead wood material present in our landscape, which is consistent with the species composition of dead wood in Västra Götalands Län and in Värmlands Län [16]. 
There was an increasing trend in dead wood volumes, irrespective of the bioenergy extraction scenario, that lasted for twenty years, after which levels decreased for the remainder of the simulation period. This decrease is likely caused by the fact that the initial forest community in our study region is rather homogeneous and relatively young (on average 40 years old), and large parts were thus not eligible for harvesting and bioenergy extraction for an additional 40 years. During this initial period, dead wood is formed due to natural processes and dead wood accumulates in mature forest before harvesting. This is also observed by field based studies that report that tree mortality rates are connected to the development of stands; higher amounts of dead wood, and of dead wood associated species, have been found in older stands [70,71]. However, when stands mature and a relatively large proportion of the stands reach the threshold age for harvesting, a larger part of the landscape becomes available for harvesting, bioenergy extraction consequently quickly increases, and the volumes of dead wood are therefore quickly reduced. This process occurs even under the conservation scenario, since harvest practices are still in place, just a smaller proportion of the live stemwood goes to the forest product sector and instead transfers to the DOM pool. It thus becomes clear that a larger proportion of live stemwood should be left in the field if the aim is to increase levels of dead wood and current harvest practices should stay in place. Alternatively, reduced harvest rates or concentrated bioenergy extraction in small parts of the landscape will likely also benefit the levels of dead wood [72,73]. We, however, did not simulate this scenario.

It is clear from the results that the conservation scenario leads to not only the highest percentage of area with high levels of dead wood, but also to the highest connectedness of the patches with relatively high levels of dead wood. Both the prognosis and the severe scenario lead to a higher dispersion of areas suitable for saproxylic beetles that prefer or are dependent on high levels of dead wood in the landscape. Numerous saproxylic species prefer dead wood of specific tree species [74,75]. Although we were able to quantify the levels of dead wood per tree species in our study, at present we cannot distinguish between the bioenergy extraction of different tree species in this model. We were therefore unable to simulate the extraction of e.g., only spruce stems. Targeted bioenergy extraction of specific tree species that are not heavily associated with saproxylic species may therefore have a lower impact than bioenergy extraction, regardless of the tree species, as simulated in our study. Some saproxylic insects e.g., pyrophilous species, have a good dispersal ability [76], but many others are not able to disperse long distances and some non-pyrophilous saproxylic taxa are clearly restricted in their dispersal [9,77-79]. Similarly, saproxylic epiphytes, like bryophytes and lichens, can have very limited dispersal ability. For these species, reduced connectivity between high quality habitat patches could severely increase the risk of stochastic extinction of metapopulations [80]. Thus, the reduced connectivity between high quality stands in our study region could be a severe threat to saproxylic diversity. There may further be knock on effects on different taxa that are associated with forest ecosystems. For example, negative impacts on saproxylic insects are likely to have far reaching effects on species higher in the food chain such as many woodpeckers [9], the loss of which may have further negative consequences for species that nest in tree cavities. This calls for careful consideration of (appropriate levels of) bioenergy extraction in forest ecosystems already void of large amounts of dead wood.

A limitation to our study was that our simulations did not take natural disturbances, such as pest outbreaks, browsing, and storm events into account. Such natural disturbances will of course increase the levels of dead wood in the landscape. We chose not to simulate these disturbances in part because it is, with climate change, increasingly hard to predict whether e.g., a pest outbreak will occur or not [81]. Furthermore, due to the stochasticity of LANDIS-II, the occurrence of a pest outbreak may be random. Even though the outbreak probability is based on certain criteria, there is still the probability that in one simulation run the outbreak does not occur, whilst in a second simulation, run the outbreak does occur. This stochasticity can therefore have large effects on the resulting amount of dead wood in the landscape and can thus obscure the effects of bioenergy extraction. We therefore caution readers that the actual levels of dead wood are highly likely going to be higher than presented 
here in this paper. In a review by Schelhaas et al [82] it was found that approximately $0.15 \%$ of the total volume of growing stock in European forests was damaged by natural disturbances in a period of 40 years. Over half of this damage was attributed to storms. Damage that is caused by bark beetles, such as Ips typographus (L.), amounted to about 8\%. Jonsson et al. [69] also suggest that much of the dead wood in managed landscapes is attributed to storm events and not to considerations during forest management. Allowing natural disturbances in forest ecosystems may therefore well be the only option to reach high levels of dead wood in forest ecosystems that have since long been stripped of large amounts of dead wood. Indeed, a species like Ips typographus (L.) has been recognized as an important ecosystem engineer or keystone species that is able to drive forest regeneration, produces dead wood, and increases heterogeneity in forest ecosystems $[83,84]$.

\section{Conclusions}

In all scenarios, dead wood decreased after an initial increase in the first two decades. This means that in landscapes dominated by young and middle-aged stands dead wood levels can be expected to decrease in the long term if no natural disturbances occur. Furthermore, when bio fuel extraction was applied, the amounts of dead wood became significantly lower in the long run. We can therefore conclude that bioenergy extraction does have significant impacts on the levels of dead wood in the landscape. Since the total levels of dead wood are already well below the suggested threshold of $20 \mathrm{~m}^{3} \mathrm{ha}^{-1}$ dead wood at which many saproxylic species can maintain viable populations [13,14], any significant decline is bound to be negative for dead wood dependent species. It therefore appears that, in our study region, it is not realistic that any scenario is going to achieve/maintain dead wood levels that are needed for biodiversity conservation without active measures to increase dead wood levels, e.g., by ecological restoration [23,85]. The methodology used and the models that were applied in our study region may also be used as a base to study the impact of (different) bioenergy extraction methods in other forest ecosystems. This type of simulations may help to achieve a sustainable forest development as well as protecting dead wood dependent species.

Author Contributions: Conceptualization, J.H., T.W., A.R.H., J.R., and T.L.; Methodology, A.R.H., J.H., T.W., J.R., and T.L; Formal Analysis, A.R.H.; Writing-Original Draft Preparation, A.R.H.; Writing-Review \& Editing, A.R.H, T.L., J.H., T.W., and J.R.; Funding Acquisition, J.H.

Funding: This research was funded by the Swedish Energy Agency under grant number P 41971-1.

Acknowledgments: We are grateful for the helpful comments of two anonymous reviewers that greatly improved the paper.

Conflicts of Interest: The authors declare no conflict of interest. The funders had no role in the design of the study; in the collection, analyses, or interpretation of data; in the writing of the manuscript, and in the decision to publish the results.

\section{References}

1. European Commission (2013). The 2020 Climate and Energy Package. European Commission. Available online: https: / / ec.europa.eu/clima/policies/strategies /2020_nl (accessed on 18 July 2018).

2. Geijer, E.; Andersson, J.; Bostedt, G.; Brannlund, R.; Hjältèn, J. Safeguarding species richness vs. increasing the use of renewable energy-The effect of stump harvesting on two environmental goals. J. For. Econ. 2014, 20, 111-125. [CrossRef]

3. Jonsell, M.; Schroeder, M. Proportions of saproxylic beetle populations that utilise clear-cut stumps in a boreal landscape-Biodiversity implications for stump harvest. For. Ecol. Manag. 2014, 334, 313-320. [CrossRef]

4. Andersson, J.; Hjältèn, J.; Dynesius, M. Wood-inhabiting beetles in low stumps, high stumps and logs on boreal clear-cuts: Implications for dead wood management. PLoS ONE 2015, 10, e0118896. [CrossRef] [PubMed]

5. Bouget, C.; Lassauce, A.; Jonsell, M. Effects of fuelwood harvesting on biodiversity-A review focused on the situation in Europe. Can. J. For. Res. 2012, 42, 1421-1432. [CrossRef] 
6. Work, T.T.; Andersson, J.; Ranius, T.; Hjältén, J. Defining stump harvesting retention targets required to maintain saproxylic beetle biodiversity. For. Ecol. Manag. 2016, 371, 90-102. [CrossRef]

7. Siitonen, J. Forest management, coarse woody debris and saproxylic organisms: Fennoscandian boreal forest as an example. Ecol. Bull. 2001, 49, 11-41.

8. Grove, S.J. Saproxylic insect ecology and the sustainable management of forests. Annu. Rev. Ecol. Syst. 2002, 33, 1-23. [CrossRef]

9. Stokland, J.N.; Siitonen, J.; Jonsson, B.G. Biodiversity in Dead Wood; Cambridge University Press: Cambridge, UK, 2012; pp. 1-509. ISBN 9781139025843.

10. Esseen, P.-A.; Ehnström, B.; Ericson, L.; Sjöberg, K. Boreal forests. Ecol. Bull. 1997, 46, $16-47$.

11. Kuuluvainen, T.; Aakala, T. Natural forest dynamics in boreal Fennoscandia: A review and classification. Silva Fenn. 2011, 45, 823-841. [CrossRef]

12. Ranius, T.; Fahrig, L. Targets for maintenance of dead wood for biodiversity conservation based on extinction thresholds. Scand. J. For. Res. 2006, 21, 201-208. [CrossRef]

13. Müller, J.; Bütler, R. A review of habitat thresholds for dead wood, A baseline for management recommendations in European forests. Eur. J. For. Res. 2010, 129, 981-992. [CrossRef]

14. Work, T.T.; Hibbert, A. Estimating species loss of saproxylic flies under scenarios of reduced coarse woody material CWM, in eastern boreal mixedwood forests. Ecosphere 2011, 2, 1-11. [CrossRef]

15. Fridman, J.; Walheim, M. Amount, structure, and dynamics of dead wood on managed forestland in Sweden. For. Ecol. Manag. 2000, 131, 23-36. [CrossRef]

16. Anonymous. Skogsdata 2016; Institutionen för skoglig resurshushållning SLU: Umeå, Sweden, 2016; pp. 1-146.

17. Paillet, Y.; Bergès, L.; Hjältén, J.; Ódor, P.; Avon, C.; Bernhardt-Römermann, M.; Bijlsma, R.-J.; De Bruyn, L.; Fuhr, M.; Grandin, U.; et al. Biodiversity differences between managed and unmanaged forests, meta-analysis of species richness in Europe. Conserv. Biol. 2010, 24, 101-112. [CrossRef] [PubMed]

18. Penttila, R.; Siitonen, J.; Kuusinen, M. Polypore diversity in managed and old-growth boreal Picea abies forests in southern Finland. Biol. Conserv. 2004, 117, 271-283. [CrossRef]

19. Kruys, N.; Jonsson, B.G. Fine woody debris is important for species richness on logs in managed boreal spruce forests of northern Sweden. Can. J. For. Res. 1999, 29, 1295-1299. [CrossRef]

20. Hjältén, J.; Stenbacka, F.; Andersson, J. Saproxylic beetle assemblages on low stumps, high tumps and logs: Implications for environmental effects of stump harvesting. For. Ecol. Manag. 2010, 26, 1149-1155. [CrossRef]

21. Persson, T.; Egnell, G. Stump harvesting for bioenergy: A review of climatic and environmental impacts in northern Europe and America. WIRES Energy Environ. 2018, e307. [CrossRef]

22. Kommissionen-mot-oljeberoende. På väg Mot ett Oljefritt Sverige; Statsrådsberedningen: Stockholm, Sweden. 2006; pp. 1-45.

23. Hof, A.R.; Hjältén, J. Are we restoring enough? Simulating impacts of restoration efforts on the suitability of forest landscapes for a locally critically endangered umbrella species. Restor. Ecol. 2017. [CrossRef]

24. Scheller, R.M.; Domingo, J.B.; Sturtevant, B.R.; Williams, J.S.; Rudy, A.; Gustafson, E.J.; Mladenoff, D.J. Design, development, and application of LANDIS-II: A spatial landscape simulation model with flexible temporal and spatial resolution. Ecol. Model. 2007, 201, 409-419. [CrossRef]

25. Scheller, R.M.; Mladenoff, D.J. A forest growth and biomass module for a landscape simulation model, LANDIS: Design, validation, and application. Ecol. Model. 2004, 180, 211-229. [CrossRef]

26. Pennanen, J.; Kuuluvainen, T. A spatial simulation approach to natural forest landscape dynamics in boreal Fennoscandia. For. Ecol. Manag. 2002, 164, 157-175. [CrossRef]

27. Scheller, R.M.; Mladenoff, D.J. A spatially interactive simulation of climate change, harvesting, wind, and tree species migration and projected changes to forest composition and biomass in northern Wisconsin, USA. Glob. Chang. Biol. 2005, 11, 307-321. [CrossRef]

28. Dymond, C.C.; Beukema, S.; Scheller, R. LANDIS-II Forest Carbon Succession Extension v2.0 User Guide. Self-published. 2015. Available online: www.landis-ii.org (accessed on 23 March 2016).

29. Dymond, C.C.; Beukema, S.; Nitschke, C.R.; Coates, K.D.; Scheller, R.M. Carbon sequestration in managed temperate coniferous forests under climate change. Biogeosciences 2016, 13, 1933-1947. [CrossRef]

30. Scheller, R.M.; Domingo, J.B. LANDIS-II Model v6 0-User Guide; Portland State University: Portland, OR, USA, 2011; pp. 1-21. 
31. Scheller, R.M.; Sturtevant, B.R.; Gustafson, E.J.; Miranda, B.R.; Zollner, P.A.; Mladenoff, D.J.; Domingo, J.B. Base Harvest v2.2 LANDIS-II Extension User Guide; Portland State University: Portland, OR, USA, 2015; pp. 1-28.

32. Bergeron, Y.; Flannigan, M.; Gauthier, S.; Leduc, A.; Lefort, P. Past, current and future fire frequency in the Canadian boreal forest, Implications for sustainable forest management. Ambio 2004, 33, 356-360. [CrossRef] [PubMed]

33. Zackrisson, O. Influence of forest fires on the North Swedish boreal forest. Oikos 1977, 29, 22-32. [CrossRef]

34. Östlund, L.; Zackrisson, O.; Axelsson, A.L. The history and transformation of a Scandinavian boreal forest landscape since the 19th century. Can. J. For. Res. 1997, 27, 1198-1206. [CrossRef]

35. Linder, P.; Östlund, L. Structural changes in three mid-boreal Swedish forest landscapes, $1885-1996$. Biol. Conserv. 1998, 851, 9-19. [CrossRef]

36. Reese, H.; Nilsson, M.; Pahen, T.G.; Hagner, O.; Joyce, S.; Tingelof, U.; Egberth, M.; Olsson, H. Countrywide estimates of forest variables using satellite data and field data from the national forest inventory. Ambio 2003, 32, 542-548. [CrossRef] [PubMed]

37. Korzukhin, M.; Rubinia, A.; Bonan, G.; Solomon, A.; Antonovsky, M. The Silvics of Some East European and Siberian Boreal Forest Tree Species; International Institute for Applied Systems Analysis: Laxenburg, Austria, 1989; pp. 1-27.

38. Perala, D.A.; Alm, A.A. Reproductive ecology of birch: A review. For. Ecol. Manag. 1990, 32, 1-38. [CrossRef]

39. Prentice, I.C.; Helmisaari, H. Silvics of north European trees, compilation, comparisons and implications for forest succession modelling. For. Ecol. Manag. 1991, 42, 79-93. [CrossRef]

40. Hofgaard, A. Structure and regeneration patterns in a virgin Picea abies forest in northern Sweden. J. Veg. Sci. 1993, 4, 601-608. [CrossRef]

41. Reyes, O.; Casal, M.; Trabaud, L. The influence of population; fire and time of dissemination on the germination of Betula pendula seeds. Plant Ecol. 1997, 133, 201-208. [CrossRef]

42. Welander, N.; Ottosson, B. The influence of shading on growth and morphology in seedlings of Quercus robur L. and Fagus sylvatica L. For. Ecol. Manag. 1998, 107, 117-126. [CrossRef]

43. Næsset, E. Decomposition rate constants of Picea abies logs in southeastern Norway. Can. J. For. Res. 1999, 293, 372-381. [CrossRef]

44. Berg, B.; Johansson, M.B.; Meentemeyer, V. Litter decomposition in a transect of Norway spruce forests, substrate quality and climate control. Can. J. For. Res. 2000, 307, 1136-1147. [CrossRef]

45. Tinner, W.; Conedera, M.; Gobet, E.; Hubschmid, P.; Wehrli, M.; Ammann, B. A palaeoecological attempt to classify fire sensitivity of trees in the southern Alps. The Holocene 2000, 10, 565-574. [CrossRef]

46. Deiller, A.F.; Walter, J.M.N.; Trémoličres, M. Regeneration strategies in a temperate hardwood floodplain forest of the Upper Rhine, sexual versus vegetative reproduction of woody species. For. Ecol. Manag. 2003, 180, 215-225. [CrossRef]

47. Pensa, M.; Jalkanan, R. Variation in needle longevity is related to needle-fascicle production rate in Pinus sylvestris. Tree Physiol. 2005, 25, 1265-1271. [CrossRef] [PubMed]

48. Mäkinen, H.; Hynynen, J.; Siitonen, J.; Sievänen, R. Predicting the decomposition of Scots pine; Norway spruce; and birch stems in Finland. Ecol. Appl. 2006, 16, 1865-1879. [CrossRef]

49. Withington, J.M.; Reich, P.B.; Oleksyn, J.; Eissenstat, D.M. Comparisons of structure and life span in roots and leaves among temperate trees. Ecol. Monogr. 2006, 763, 381-397. [CrossRef]

50. Chalupka, W. Reproduction. In Biology and Ecology of Norway Spruce; Tjoelker, M.G., Boratynski, A., Bugala, W., Eds.; Springer: Dordrecht, The Netherlands, 2007; pp. 97-114, ISBN 978-1-4020-4841-8.

51. Modrzynski, J. Outline of Ecology. In Biology and Ecology of Norway Spruce; Tjoelker, M.G., Boratynski, A., Bugala, W., Eds.; Springer: Dordrecht, The Netherlands, 2007; pp. 195-253, ISBN 978-1-4020-4841-8.

52. Proença, V.A.M. Galicio-Portuguese Oak Forest of Quercus robur and Quercus pyrenaica, Biodiversity Patterns and Forest Response to Fire. Ph.D. Dissertation, Universidade de Lisboa, Lisbon, Portugal, 2009; p. 172.

53. Kurz, W.A.; Dymond, C.C.; White, T.M.; Stinson, G.; Shaw, C.H.; Rampley, G.J.; Smyth, C.; Simpson, B.N.; Neilson, E.T.; Trofymow, J.A.; et al. CBM-CFS3, a model of carbon-dynamics in forestry and land-use change implementing IPCC standards. Ecol. Model. 2009, 2204, 480-504. [CrossRef] 
54. Conedera, M.; Lucini, L.; Valese, E.; Ascoli, D.; Pezzati, G.B. Fire resistance and vegetative recruitment ability of different deciduous trees species after low-to moderate-intensity surface fires in southern Switzerland. In Proceedings of the VI International Conference on Forest Fire Research, Coimbra, Portugal, 15-18 November 2010; Viegas, D.X., Ed.; University of Coimbra: Coimbra, Portugal, 2010; pp. 15-18.

55. Hansson, K.; Helmisaari, H.S.; Sah, S.P.; Lange, H. Fine root production and turnover of tree and understorey vegetation in Scots pine; silver birch and Norway spruce stands in SW Sweden. For. Ecol. Manag. 2013, 309, 58-65. [CrossRef]

56. Anonymous. Skogsvårds Lagstiftningen, Gällande Regler 1 April 2017; Skogsstyrelsen: Jönköping, Sweden, 2017; pp. 1-92, ISBN 978-91-87535-06-2.

57. Nilsson, P.; Cory, N. Forestry Statistics 2013; Swedish University of Agricultural Sciences: Umeå, Sweden, 2013; pp. 1-158.

58. Sandström, F.; Petersson, H.; Kruys, N.; Ståhl, G. Biomass conversion factors density and carbon concentration, by decay classes for dead wood of Pinus sylvestris, Picea abies and Betula spp. in boreal forests of Sweden. For. Ecol. Manag. 2007, 243, 19-27. [CrossRef]

59. Krankina, O.N.; Harmon, M.E. Dynamics of the dead wood carbon pool in northwestern Russian boreal forests. Water Air Soil Pollut. 1995, 82, 227-238. [CrossRef]

60. Sollins, P.; Cline, S.P.; Verhoeven, T.; Sachs, D.; Spycher, G. Patterns of log decay in old-growth Douglas-fir forests. Can. J. For. Res. 1987, 17, 1585-1595. [CrossRef]

61. Groombridge, B. Global Biodiversity, Status of the Earth's Living Resources; Chapman and Hall: New York, NY, USA, 1992; pp. 1-585, ISBN 978-94-011-2282-5.

62. Gustafson, E.J.; Parker, G.R. Relationships between landcover proportion and indices of landscape spatial pattern. Landsc. Ecol. 1992, 7, 101-110. [CrossRef]

63. McGarial, K.; Marks, B. FRAGSTAT, Spatial Pattern Analysis Program for Quantifying Landscape Structure; United States Department of Agriculture Pacific Northwest Research Station: Portland, OR, USA, 1995; p. 122. [CrossRef]

64. McGarical, K.; Cushman, S.A.; Ene, E. FRAGSTATS v4, Spatial Pattern Analysis Program for Categorical and Continuous Maps; University of Massachusetts: Amherst, MA, USA, 2012; Available online: http:/ / www.umass.edu/landeco/research/fragstats/fragstats.html (accessed on 18 March 2018).

65. The R Foundation for Statistical Computing Platform. R version 3.2.2. 2015. Available online: http:/ / www.r-project.org/ (accessed on 6 December 2015).

66. Hijmans, R.J.; van Etten, J.; Cheng, J.; Mattiuzzi, M.; Sumner, M.; Greenberg, J.A.; Perpinan Lamigueiro, O.; Bevan, A.; Racine, E.B.; Ashton Shortridge, A.; et al. Raster: Geographic Data Analysis and Modeling; $\mathrm{R}$ package version 2.6-7. 2017. Available online: https://cran.r-project.org/web/packages/raster/ (accessed on 27 July 2018).

67. Wickham, H. ggplot2: Elegant Graphics for Data Analysis; Springer: New York, NY, USA, 2009.

68. Lindenmayer, D.B.; Franklin, J.F.; Lõhmus, A.; Baker, S.C.; Bauhus, J.; Beese, W.; Brodie, A.; Kiehl, B.; Kouki, J.; Martínez Pastur, G.; et al. A major shift to the retention approach for forestry can help resolve some global forest sustainability issues. Conserv. Lett. 2012, 5, 421-431. [CrossRef]

69. Jonsson, B.G.; Ekström, M.; Esseen, P.A.; Grafström, A.; Ståhl, G.; Westerlund, B. Dead wood availability in managed Swedish forests-Policy outcomes and implications for biodiversity. For. Ecol. Manag. 2016, 376, 174-182. [CrossRef]

70. Aakala, T.; Kuuluvainen, T.; Wallenius, T.; Kauhanen, H. Contrasting patterns of tree mortality in late-successional Picea abies stands in two areas in northern Fennoscandia. J. Veg. Sci. 2009, 20, 1016-1026. [CrossRef]

71. Stenbacka, F.; Hjältén, J.; Hilszczański, J.; Dynesius, M. Saproxylic and non-saproxylic beetle assemblages in boreal spruce forests of different age and forestry intensity. Ecol. Appl. 2010, 20, 2310-2321. [CrossRef] [PubMed]

72. Johansson, V.; Felton, A.; Ranius, T. Long-term landscape scale effects of bioenergy extraction on dead wood-dependent species. For. Ecol. Manag. 2016, 371, 103-113. [CrossRef]

73. Green, P.; Peterken, G.F. Variation in the amount of dead wood in the woodlands of the Lower Wye Valley, UK in relation to the intensity of management. For. Ecol. Manag. 2017, 98, 229-238. [CrossRef]

74. Toivanen, T.; Kotiaho, J.S. The preferences of saproxylic beetle species for different dead wood types created in forest restoration treatments. Can. J. For. Res. 2010, 40, 445-464. [CrossRef] 
75. Hägglund, R.; Hjältén, J. Substrate specific restoration promotes saproxylic beetle diversity in boreal forest set-asides. For. Ecol. Manag. 2018, 425, 45-58. [CrossRef]

76. Schmitz, H.; Bousack, H. Modelling a historic oil-tank fire allows an estimation of the sensitivity of the infrared receptors in pyrophilous Melanophila beetles. PLoS ONE 2012, 7, e37627. [CrossRef] [PubMed]

77. Brunet, J.; Isacsson, G. A comparison of the saproxylic beetle fauna between lowland and upland beech forests in southern Sweden. Ecol. Bull. 2010, 53, 131-139.

78. Ranius, T. Measuring the dispersal of saproxylic insects, a key characteristic for their conservation. Popul. Ecol. 2006, 48, 177-188. [CrossRef]

79. Schiegg, K. Effects of dead wood volume and connectivity on saproxylic insect species diversity. Ecoscience 2000, 7, 290-298. [CrossRef]

80. Hanski, I. Insect conservation in boreal forests. J. Insect Conserv. 2008, 12, 451-454. [CrossRef]

81. Hof, A.R.; Svahlin, A. The potential effect of climate change on the geographical distribution of insect pest species in the Swedish boreal forest. Scand. J. For. Res. 2016, 31, 29-39. [CrossRef]

82. Schelhaas, M.J.; Nabuurs, G.J.; Schuck, A. Natural disturbances in the European forests in the 19th and 20th centuries. Glob. Chang. Biol. 2003, 9, 1620-1633. [CrossRef]

83. Müller, J.; Bußler, H.; Goßner, M.; Rettelbach, T.; Duelli, P. The European spruce bark beetle Ips typographus in a national park: from pest to keystone species. Biodivers. Conserv. 2008, 17, 2979. [CrossRef]

84. Martikainen, P.; Siitonen, J.; Kaila, L.; Punttila, P.; Rauh, J. Bark beetles (Coleoptera, Scolytidae) and associated beetle species in mature managed and old-growth boreal forests in southern Finland. For. Ecol. Manag. 1999, 116, 233-245. [CrossRef]

85. Hjältén, J.; Hägglund, R.; Johansson, T.; Roberge, J.-M.; Dynesius, M.; Olsson, J. Forest restoration by burning and gap cutting yield distinct immediate effects on saproxylic beetles. Biol. Conserv. 2017, 26, 1623-1640. [CrossRef]

(C) 2018 by the authors. Licensee MDPI, Basel, Switzerland. This article is an open access article distributed under the terms and conditions of the Creative Commons Attribution (CC BY) license (http:/ / creativecommons.org/licenses/by/4.0/). 